ISSN 0258-7122

Bangladesh J. Agril. Res. 38(2): 219-225, June 2013

\title{
GENOTYPIC AND PHENOTYPIC CORRELATION AND PATH ANALYSIS IN DURUM WHEAT (Triticum turgidum L. var. durum)
}

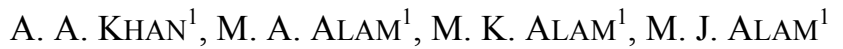 \\ AND Z. I. SARKER ${ }^{2}$
}

\begin{abstract}
An experiment was conducted at Regional Agricultural Research Station, Ishurdi during the 2009-10 cropping season with the objective of estimating the associations between yield and yield-related traits and to identify direct and indirect effects of characters on grain yield in durum wheat. The result showed significant variation among the genotypes for all the characters studied. Significant positive correlation was found for plant height, number of spikes $/ \mathrm{m}^{2}$ and 1000-grain weight with grain yield. Heading days and maturity days showed negative correlation with grain yield. Maturity days, number of spikes $/ \mathrm{m}^{2}$ and 1000 -grain weight had significant positive direct effects on grain yield. Number of grains/spike had also direct positive effect, but in low magnitude. The indirect effect of heading days and plant height on grain yield was found mainly through maturity days and 1000-grain weight. It can be concluded that emphasis should be given on heading days and plant height along with 1000-grain weight, number of spikes $/ \mathrm{m}^{2}$ and number of grains/spike for selection of durum wheat genotypes.
\end{abstract}

Keywords: Durum wheat, correlation, path analysis.

\section{Introduction}

Durum wheat usually attracts a significant premium over bread wheat. The agronomic adaptability of durum has attracted a number of farmers. It is widely grown in most part of the wheat growing areas of the world. Durum wheat is a major crop in the Mediterranean basin of West Asia, North Africa, and Southern Europe (Elias and Manthey, 2005). Durum grain is consumed as flat, unleavened bread, 'Couscous' and 'Bulgur' in North Africa and Middle East and as 'Chapatis' in India. About half of the world's durum production is converted into 'Pasta' products. In Bangladesh, there is no durum wheat variety till now, but it is becoming and increasingly viable option here.

Success of a breeding programme depends on numerous factors. Selection of a right variety for a particular region is an important one. Yield component concept in breeding has got much importance in improving yield potentiality.

${ }^{1}$ Scientific Officer, Regional Agricultural Research Station, Bangladesh Agricultural Research Institute (BARI), Ishurdi, Pabna, ${ }^{2}$ Principal Scientific Officer, Wheat Research Centre, BARI, Nashipur, Dinajpur, Bangladesh. 
Initiating a breeding programme based on the yield components requires the knowledge of relationship between the yield and its component characters. In this connection, determination of correlation coefficients between the characters has a considerable importance in selecting breeding materials (Afroz et al., 2004). On the other hand, path coefficient analysis has been found to give more specific information on the direct and indirect influence of each of the component characters upon grain yield. Therefore, the present study was undertaken to find out relationship between yield and its component characters and the causes of such relations was further analyzed.

\section{Materials and Method}

Eight advanced lines of durum wheat along with two check varieties one from $T$. durum (BDW-8) and the other from T. astivum (Prodip) were evaluated at Regional Agricultural Research Station, Ishurdi during the winter season of 2009-10 under irrigated and optimum seeding condition. The experiment was laid out in randomized complete block design (RCBD) with four replications. The unit plot size was $5 \mathrm{~m} \times 1.6 \mathrm{~m}, 8$ rows at $20 \mathrm{~cm}$ spacing. Data were collected from cach plot on seven characters, namely days to heading, days to maturity, plant height, number of spikes $/ \mathrm{m}^{2}$, number of grains/spike, 1000-grain weight and grain yield. The analysis of variance for different characters were measured followed by Steel and Torrie (1960) and the means were separated by Duncan's New Multiple Rang Test (DMRT). Genotypic and phenotypic correlation coefficients were obtained as suggested by Johnson, et al. (1955) and path coefficient analysis was done as per Dewey and Lu (1959).

\section{Results and Discussion}

The average performances of the advanced lines for different characters are presented in Table 1. Statistically significant differences were observed among the genotypes for all the traits studied. Grain yield ranged from 4469 to 5578 kg/ha. Genotypes D-001, D-002 and D-007 yielded high but statistically similar to the control. The control variety Prodip produced the tallest plants (102.9 $\mathrm{cm}$ ). The plant height is very important in terms of resistance to lodging and harvest index (Dogan, 2009). Many researchers reported that ideal plant height ranged from 90 to $100 \mathrm{~cm}$ (Tosun, 1987 and Yürür, 1998) It also showed the lowest heading and maturity days, but significantly higher means for rest of the characters. 
Table 1. Mean performances of the durum wheat genotypes for seven characters.

\begin{tabular}{|c|c|c|c|c|c|c|c|}
\hline Genotypes & Heading days & Maturity days & $\begin{array}{l}\text { Plant height } \\
\text { (cm) }\end{array}$ & Spikes $/ \mathrm{m}^{2}$ (no.) & $\begin{array}{l}\text { Grains/spike } \\
\text { (no.) }\end{array}$ & $\begin{array}{c}1000 \text {-grain wt } \\
\text { (g) }\end{array}$ & $\begin{array}{l}\text { Grain yield } \\
\text { (kg/ha) }\end{array}$ \\
\hline D-001 & $75.50 \mathrm{c}$ & $109.50 \mathrm{bc}$ & $89.20 \mathrm{bc}$ & 298.00a-d & 46.75b-d & $33.85 \mathrm{~cd}$ & 5125a-c \\
\hline D-002 & $75.75 \mathrm{bc}$ & $110.00 \mathrm{bc}$ & $90.55 \mathrm{bc}$ & 316.80ab & $50.25 \mathrm{ab}$ & 33.88cd & 5078a-c \\
\hline D-003 & $77.75 a$ & $109.80 \mathrm{bc}$ & $88.15 \mathrm{~cd}$ & 290.80b-d & 47.47a-d & $31.85 \mathrm{~cd}$ & $4516 c$ \\
\hline D-004 & 73.50d & $107.80 \mathrm{~d}$ & $85.05 d$ & 289.50b-d & $45.72 \mathrm{~b}-\mathrm{d}$ & $28.19 e$ & $4469 c$ \\
\hline D-005 & 76.75a-c & $108.80 \mathrm{~cd}$ & 87.60cd & 287.30b-d & $53.25 a$ & $31.21 \mathrm{~d}$ & 4906bc \\
\hline D-006 & $75.75 c$ & 109.00c & 88.05cd & 279.80cd & 41.53d & $34.76 \mathrm{c}$ & $4906 \mathrm{bc}$ \\
\hline D-007 & $77.75 a$ & 109.30c & $92.05 b$ & $300.50 a-d$ & $43.05 \mathrm{~cd}$ & $33.24 \mathrm{~cd}$ & 4969a-c \\
\hline D-008 & 78.50a & 110.80ab & $88.05 \mathrm{~cd}$ & $269.80 \mathrm{~d}$ & 48.03a-c & $38.03 b$ & 4859bc \\
\hline BDW-8 (ck) & 77.50ab & 111.50a & $88.05 \mathrm{~cd}$ & $329.00 a$ & $44.20 \mathrm{~b}-\mathrm{d}$ & $34.67 \mathrm{c}$ & 5234ab \\
\hline Prodip (ck) & $69.50 \mathrm{e}$ & $103.80 \mathrm{e}$ & 102.90a & $312.30 \mathrm{a}-\mathrm{c}$ & 47.75a-d & $44.50 \mathrm{a}$ & 5578a \\
\hline
\end{tabular}

Means of the same column followed by the same letter do not differ significantly at $5 \%$ level of probability. 
The phenotypic and genotypic correlation coefficients among the characters are presented in Table 2. The genotypic correlation coefficients were higher than their corresponding phenotypic correlation in most of the cases which indicated that the association was largely due to genetic factors.

Table 2. Genotypic $\left(r_{g}\right)$ and phenotypic $\left(r_{p}\right)$ correlation coefficients among the yield and its components in durum wheat.

\begin{tabular}{|c|c|c|c|c|c|c|c|}
\hline Character & & $\begin{array}{c}\text { Maturity } \\
\text { days }\end{array}$ & $\begin{array}{l}\text { Plant } \\
\text { height } \\
(\mathrm{cm})\end{array}$ & $\begin{array}{c}\text { Spikes } / \mathrm{m}^{2} \\
\text { (no.) }\end{array}$ & $\begin{array}{c}\text { Grains/ } \\
\text { spike } \\
\text { (no.) }\end{array}$ & $\begin{array}{c}1000- \\
\text { grain wt } \\
(\mathrm{g})\end{array}$ & $\begin{array}{c}\text { Grain } \\
\text { yield } \\
(\mathrm{kg} / \mathrm{ha})\end{array}$ \\
\hline \multirow[t]{2}{*}{ Heading days } & $r_{g}$ & $0.956 * *$ & $-0.701^{*}$ & -0.274 & -0.111 & -0.489 & -0.504 \\
\hline & $r_{p}$ & $0.810^{* *}$ & $-0.632 *$ & -0.260 & 0.039 & -0.418 & -0.411 \\
\hline \multirow[t]{2}{*}{ Maturity days } & $\mathrm{r}_{\mathrm{g}}$ & & $-0.784 * *$ & -0.099 & -0.147 & -0.520 & -0.455 \\
\hline & $r_{p}$ & & $-0.657^{*}$ & 0.011 & -0.028 & -0.393 & -0.250 \\
\hline \multirow[t]{2}{*}{ Plant height } & $r_{g}$ & & & 0.390 & 0.047 & $0.883 * *$ & $0.936^{* *}$ \\
\hline & $r_{p}$ & & & 0.416 & 0.065 & $0.741 *$ & 0.587 \\
\hline \multirow[t]{2}{*}{ Spikes $/ \mathrm{m}^{2}$} & $r_{g}$ & & & & -0.180 & 0.258 & $0.742 *$ \\
\hline & $r_{p}$ & & & & 0.137 & 0.097 & 0.459 \\
\hline \multirow[t]{2}{*}{ Grains/spike } & $r_{g}$ & & & & & -0.032 & -0.015 \\
\hline & $r_{p}$ & & & & & 0.020 & 0.071 \\
\hline \multirow[t]{2}{*}{1000 -grain wt } & $r_{g}$ & & & & & & $0.99 * *$ \\
\hline & $r_{p}$ & & & & & & 0.539 \\
\hline
\end{tabular}

$*$ and ** indicate significant at $5 \%$ and $1 \%$ levels of probability, respectively.

Grain yield was positively associated with plant height, number of spikes $/ \mathrm{m}^{2}$, and 1000-grain weight both at genotypic and phenotypic levels but significant only at genotypic level. Nofouzi et al. (2008) reported significant and positive correlation between grain yield and plant height. Significant and positive correlation among number of productive tillers per plant and grain yield was also noticed by Ali et al. (2008) in wheat. This result is also in consistent with the findings of Dogan (2009) and Gashaw et al. (2007). They reported significant positive correlation between grain yield and 1000-grain weight. Days to heading and days to maturity displayed a non-significant genotypic and phenotypic correlation with yield and 1000-grain weight, but their correlations were considerably high and negative. Similar result of non-significant and negative association of grain yield and maturity days was observed by Subhashchandra et al. (2009) and Gashaw et al. (2007). It indicated that the opportunity for fixation of photosynthates and its translocation to developing grains was short due to increasing vegetative phase which caused significant reduction of grain yield and grain size. The correlations of number of grains/spike with grain yield and 1000- 
grain weight were negative at genotypic level and low in magnitude which indicated that higher grain number adversely affected grain size and ultimately reduced grain yield.

Plant height showed significant and positive correlation with 1000-grain weight at both genotypic and phenotypic levels. It was also positively associated with number of spikes $/ \mathrm{m}^{2}$ and number of grains/spike. On the contrary, it was found negative and significant at both levels with heading days suggesting that tall plants showed low heading days resulting longer reproductive phase that accumulated more photosynthates to the grains and thus, made highly significant positive correlation between plant height and grain yield. Similar findings were also reported by Shamsuddin and Ali (1998) in wheat. They stated that tall plants gave high yield/plant through grain number and size. On the other hand, plant height showed significant negative association with maturity days which supports the findings of Subhashchandra et al. (2009). Days to maturity showed considerable negative correlation with all the traits studied. Considerable negative correlations were also observed for heading days with all the traits except maturity days, suggesting shorter vegetative phase along with longer reproductive phase would contribute to higher grain yield.

The path coefficient analysis appeared to provide a clue to the contribution of various components of yield to overall grain yield in the genotypes under study. It provides an effective way of finding out direct and indirect sources of correlation. In this study grain yield represented the dependent variable and days to heading, days to maturity, plant height, number of spikes $/ \mathrm{m}^{2}$, number of grains/spike and 1000-grain weight were the independent ones. Direct and indirect effects of these components determined on grain yield and their contribution ratios are summarized in table 3 .

The path coefficient analysis of genotypic correlations among the traits revealed that 1000-grain weight exerted the highest direct positive effect $(0.661)$ on grain yield followed by maturity days $(0.594)$, number of spikes $/ \mathrm{m}^{2}(0.392)$ and number of grains/spike (0.107). Yagdi (2009) noticed that thousand kernel weights increased the yield with the direct effect value of 0.286 . Direct effect of number of spikes $/ \mathrm{m}^{2}$ had a proportion of $43.75 \%$. This result partially supports the findings of Subhashchandra et al. (2009) and Ali et al. (2008) for the direct effect of productive tillers per plant on grain yield. Dogan (2009) reported direct positive effect of grain number of spike and 1000-grain weight on yield. Plant height also showed considerable amount of positive direct effect $(0.431)$ on grain yield. Ashraf et al. (2002) found positive direct effect of plant height on grain yield per plant. Ali et al. (2008) suggested that preference must be given on the number of productive tillers plant and number of grains per spike during selection along with optimum plant height to select superior wheat genotypes. 
Days to heading and plant height showed the highest positive indirect effects on grain yield via maturity days and 1000 -grain weight. Number of spike $/ \mathrm{m}^{2}$ had significant indirect positive effect via 1000-grain weight and plant height on grain yield. Number of grains/spike and plant height exhibited negative indirect effect via maturity days with a proportion of 25.24 and $24.92 \%$, respectively. Thousand grain weight and maturity days showed considerable amount of indirect effects on grain yield via plant height. Percentages of these indirect effects were 23.56 and $20.54 \%$, respectively.

Table 3. Path analysis of yield components on yield of durum wheat.

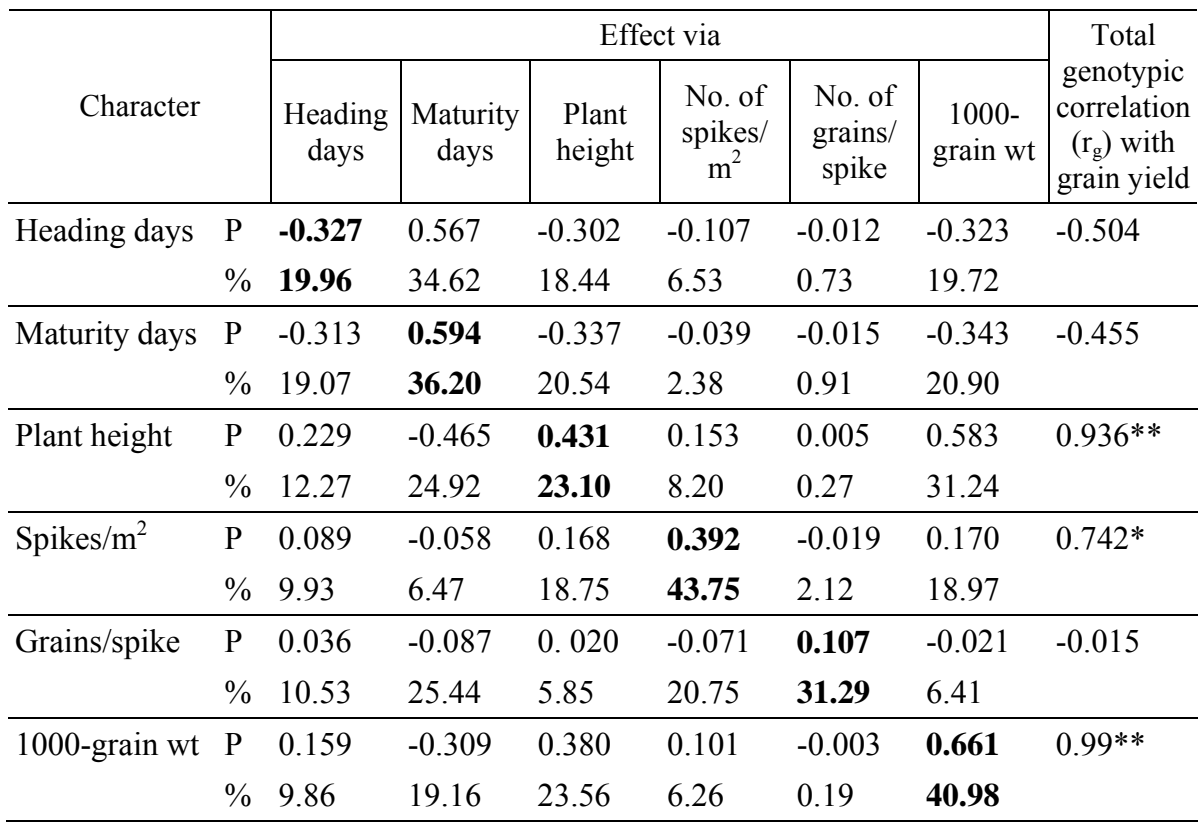

Residual effect $=\sqrt{ }-0.241$.

Bold figures in diagonal line indicates direct effects.

$\mathrm{P}=$ Path coefficient; $\%=$ Percentage direct and indirect effects.

$*$ and $* *$ indicate significant at $5 \%$ and $1 \%$ levels of probability, respectively.

From the correlation and path coefficient analysis, it is evident that primary emphasis should be given on heading days and plant height, the next importance to be given on 1000-grain weight, number of spikes $/ \mathrm{m}^{2}$ and number of grains/spike during selection of durum wheat. Many of earlier studies (Kumar and Hunshal, 1998; Garcia et al., 2003; Ali et al., 2008; Dogan, 2009, and Subhashchandra et al.,2009) indicated that plant height, number of spikes $/ \mathrm{m}^{2}$, number of grains/spike, and 1000-grain weight were the main contributors to grain yield in durum wheat which supported the present findings. 


\section{References}

Afroz, R., M.S.H. Sharif and L. Rahman. 2004. Genetic variability, correlation and path analysis in mustard amd rape (Brassica spp.). Bangladesh J. PI. Breed. Genet. 17(1): 59-63.

Ali, Y., B.M. Atta, J. Akhter, P. Monneveux and Z. Lateef. 2008. Genetic variabiligy, association and diversity studies in wheat (Triticum aestivum L.) germplasm. Pak. J. Bot. 40(5): 2087-2097.

Ashraf, M., A. Ghafoor, N.A. Khan amd M. Yousaf. 2002. Path coefficient in wheat under rainfed conditions. Pak. J. Agric. Res. 17: 1-6.

Dewey, D.R. and K.H. Lu. 1959. A correlation and path-coefficient analysis of components of crested wheatgrass grain production. Agron. J. 51: 515-518.

Dogan, R. 2009. The correlation and path coefficient analysis for yield and some yield components of durum wheat (Triticum turgidum var. durum L.) in west Anatolia conditions. Pak. J. Bot. 41(3): 1081-1089.

Elias, E.M., F.A. Manthey. 2005. End products. In: Royo, C., M.N. Nachit, N. Di fonzo, J.L. Araus, W.H. Pfeiffer and G.A. Slafer (eds.) Durum wheat breeding. Current approaches and future strategies. New York: Food Academic Press, The Haworth Press, 63-86.

Garcia, L.F., Y. del Moral, D. Rharrabti, Villagas and C. Royo. 2003. Evaluation of grain yield and its components in durum wheat under Mediterranean conditions. Agron. J. 95: 266-274.

Gashaw, A., H. Mohammed and H. Singh. 2007. Selection criterion for improved crain yields in Ethiopian drum wheat genotypes. African Crop Sci. J. 15(1): 25-31.

Johnson, H.W., H.F. Robinson and R.E. Comstock. 1955. Estimation of genetic and environmental variability in soybean. Agron. J. 47: 314-318.

Kumar, B.N.A. and C.S. Hunshal. 1998. Correlation and path coefficient analysis in durum wheats (Triticum durum Desf.) under different planting dates. CropResearch-Hisar 16(3): 358-361.

Nofouzil, F., V. Rashidi and A.R. Tarinejad. 2008. Path analysis of grain yield with its components in durum wheat under drought stress. International meeting on soil fertility land management and agroclimatology, Turkey Pp. 681-686.

Shamsuddin. A.K.M. and M.M. Ali. 1989. Genotypic and phenotypic correlation and path analysis in spring wheat. Bangladesh J. Agril. Sci. 16(1): 75-78.

Steel, R.G.D. and J.H. Torrie. 1960. Principles and procedures of statistics, Mc-Graw Hill Book Co., Inc. New York.

Subhashchandra, B., H.C. Lohithaswa, S.A. Desai, R.R. Hanchinal, I.K. Kalappanavar, K.K. Math and P.M. Salimath. 2009. Assessment of genetic variability and relationship between genetic diversity and transgressive segregation in tetraploid wheat. Karnataka J. Agric. Sci. 22(1): 36-38.

Tosun, O. 1987. Türkiye'nin Tahıl Yetiştirme Sorunları ve Bunların Çözüm Yolları. Türkiye Tahıl Simpozyumu (Tübitak), Bursa.

Yagdi, K. 2009. Path coefficient analysis of some yield components in durum wheat (Triticum durum desf.). Pak. J. Bot. 41(2): 745-751.

Yürür, N. 1998. Serin İklim Tahılları (Tahılları-I) U.Ü. Basımevi, 171-172. 